\title{
Lusioersily
}

\section{Methotrexate combination effects with genistein and daidzein on MDA-MB-231 breast cancer cell viability}

Maginnes, A., \& Owusu-Apenten, R. K. (2017). Methotrexate combination effects with genistein and daidzein on MDA-MB-231 breast cancer cell viability. Journal of Applied Life Sciences International, 13(1), 1-9.

Link to publication record in Ulster University Research Portal

Published in:

Journal of Applied Life Sciences International

Publication Status:

Published (in print/issue): 25/07/2017

\section{Document Version \\ Author Accepted version}

\section{General rights}

Copyright for the publications made accessible via Ulster University's Research Portal is retained by the author(s) and / or other copyright owners and it is a condition of accessing these publications that users recognise and abide by the legal requirements associated with these rights.

\section{Take down policy}

The Research Portal is Ulster University's institutional repository that provides access to Ulster's research outputs. Every effort has been made to ensure that content in the Research Portal does not infringe any person's rights, or applicable UK laws. If you discover content in the Research Portal that you believe breaches copyright or violates any law, please contact pure-support@ulster.ac.uk. 


\title{
Methotrexate Combination Effects with Genistein and Daidzein on MDA-MB-231 Breast Cancer Cell Viability
}

\author{
Ashleigh Maginnes ${ }^{1}$ and Richard Owusu-Apenten ${ }^{1^{*}}$ \\ ${ }^{1}$ Nutrition Innovations Centre for Food and Health (NICHE), School of Biomedical Sciences, \\ Ulster University, Cromore Road, Coleraine, BT52 1SA, United Kingdom.
}

Authors' contributions

This work was carried out in collaboration between both authors. Author ROA designed the study, wrote the protocol, performed NLR and CompuSyn analysis and wrote the first draft of the manuscript.

Author AM managed the literature searches, conducted data collection, performed the statistical analysis and wrote the MSc thesis from which this paper derives. Both authors read and approved the final manuscript.

Article Information

DOI: 10.9734/JALSI/2017/35206
$\frac{\text { Editor(s): }}{(1)}$
$(2)$
$\frac{\text { Reviewers: }}{(1)}$
$(2)$
$(3)$
Complete Peer review History:

Short Research Article

Received $30^{\text {th }}$ June 2017

Accepted 22 $2^{\text {nd }}$ July 2017

Published 25 $5^{\text {th }}$ July 2017

\section{ABSTRACT}

Aims: To investigate the effect of methotrexate and soy isoflavones genistein and daidzein on MDA-MB-231 breast cancer cell viability.

Study Design: In-vitro study using cultured cells

Place and Duration of Study: Nutrition Innovations Centre for Food \& Health (NICHE), School of Biomedical Sciences, Ulster University, data collected September 2014-2015.

Methods: Human breast cancer MDA-MB-231 cells were cultured in DMEM (with 10\% FBS, 1\% Pen strep) and treated with methotrexate, genistein or daidzein for $72 \mathrm{hrs}$. Combinations treatments used non-fixed ratios of methotrexate $(0-100 \mu \mathrm{M})$ and genistein or daidzein $(30 \mu \mathrm{M})$ with cell viability monitored using the MTT assay.

Results: The $50 \%$ effect dose (EC50) was $44.7 \pm 6.4 \mu \mathrm{M}$ for methotrexate, $55.8 \pm 3.9 \mu \mathrm{M}$ for genistein or $67.4 \pm 12.2 \mu \mathrm{M}$ for daidzein. Combination treatments with genistein or daidzein 
produced EC50 of $57.6 \pm 2.0$ or $29.7 \pm 2.4 \mu \mathrm{M}$ for methotrexate, respectively. The combination index (Cl) was 1.9 for methotrexate-genistein whilst $\mathrm{Cl}$ was 1.1 for methotrexate-daidzein near the median dose. Values for $\mathrm{Cl}$ decreased from 5.0 towards 1.0 as the ratio of methotrexate: isoflavone increased. The results are discussed in terms of prevailing ideas concerning how phytochemicals affects drug adsorption, distribution, metabolism and excretion (ADME) and the expected consequences for cytotoxicity.

Conclusions: Treatment of MDA-MB-231 breast cancer cells with methotrexate and genistein or daidzein produces interactions consistent with antagonism $(\mathrm{Cl}=1.1-5.0)$ but the effects are predicted to diminish with rising methotrexate to isoflavone ratio.

Keywords: Methotrexate; breast cancer; isoflavones; genistein; daidzein; interactions.

\section{INTRODUCTION}

Methotrexate is used frequently for treating leukemia, solid tumors and rheumatoid arthritis [1]. Acquired resistance to methotrexate [2] prompts high-dose therapy leading to a likelihood of toxic side-effects [3]. Combination therapy with antioxidant phytochemicals was proposed to mitigate the toxic side effects associated with methotrexate but the impact on drug effectiveness remains controversial $[4,5,6]$. Observational studies showed there were low rates of breast cancer incidence in Asian women linked to the consumption of soy products [7]. A variety of soybean products were found to prevent methotrexate gastro-intestinal toxicity, but the anti-apoptotic components appeared to be relatively high molecular weight $(>10 \mathrm{kd})$ compounds [8]. Soy isoflavones possess anticancer activity $[9,10]$. Genistein produces synergisms with other anticancer agents due to a chemo-sensitizing effect $[10,11]$.

To our knowledge no investigation of the effect of soy isoflavones on methotrexate cytotoxicity towards breast cancer cells has been published. The aim of this study was to investigate the effect of methotrexate combined with soy isoflavones genistein and daidzein on MDA-MB-231 breast cancer cell viability. The approach conforms to a variable ratio method for assessing interactions using the median effect model detailed by Chou and co-workers [12].

\section{MATERIALS AND METHODS}

Methotrexate, genistein, daidzein, 3-(4,5dimethyl thiazol-2-yl)-2,5-diphenyl tetrazolium bromide (MTT), dimethyl Sulfoxide (DMSO) and other chemicals were obtained from SigmaAldrich (UK). Human breast cancer cell line MDAMB-231 was from American Type Cell Culture Collection (LGC Standards Teddington, Middlesex, UK). Dulbecco's Modified Eagle's Medium (DMEM) type 31885 (with low glucose),
Fetal bovine serum (FBS), Trypsin (1X) and consumables for cell culture were from Fischer Scientific- Invitrogen Ltd (UK).

\subsection{Cell Culture}

MDA-MB-231 breast cancer cells were cultured using DMEM medium supplemented with $+10 \%$ FBS and $1 \%$ pen step. Culture flasks and $96-$ well micro-plates were incubated at $37^{\circ} \mathrm{C}$ in a $5 \%$ $\mathrm{CO}_{2}$ atmosphere (LEEC Research $\mathrm{CO}_{2}$ Incubator, LEEC Ltd., Nottingham, UK). Cells were trypsinized, counted using a NucleoCounter (model NC-3000, ChemoMetec, Allerod, Denmark) and seeded at 10,000 cells/well in 96 well plates with $50 \mu \mathrm{l}$ media per well. Cells were incubated overnight at $37^{\circ} \mathrm{C}$ to allow attachment.

Stock solutions of methotrexate, genistein, and daidzein $(100 \mathrm{mM})$ were prepared with DMSO, diluted 10 fold with DMEM and sterilized with 0.2 $\mu \mathrm{m}$ cellulose acetate filters before use. Sterilized solutions were serially diluted to achieve $2 x$ target concentration (max; $200 \mu \mathrm{M}$ with $\leq 0.05 \%$ DMSO final concentration). Cells were treated with methotrexate, genistein or daidzein alone and incubated for 72 hours. Cell viability was determined using the MTT assay (Section 2.2.). These tests were analyzed to find EC50 values and such data were used for the design of combination studies.

\subsection{MTT Assay}

Microwell plates were washed $\times 2$-fold with ice cold PBS $(100 \mu \mathrm{l})$ with a third wash remaining in the wells. MTT reagent $20 \mu \mathrm{l}(5 \mathrm{mg} / \mathrm{ml}$ in PBS buffer) was added per well and plates were incubated at $37^{\circ} \mathrm{C}$ for 2 hours. Blue formazan crystals formed were dissolved by adding $100 \mu \mathrm{l}$ isopropanol (with $0.04 \mathrm{~N} \mathrm{HCl}$ ) and incubating for one hour. Absorbances were measured at 570 $\mathrm{nm}$ using a microplate reader (VersaMax ${ }^{\mathrm{TM}}$ ELISA microplate reader, Molecular Devices, Sunnyvale, CA, USA.).Data were expressed as 
mean \pm standard error of means (SEM) of 2independent experiments with six-replicate (microwells) per treatment-concentration $(n=12)$.

\subsection{Combination Studies}

Samples containing ( $4 \mathrm{x}$ target concentration) methotrexate $(25 \mu \mathrm{l})$ were added to microplate wells containing 10,000 seeded cells and $50 \mu \mathrm{l}$ of culture media. Then $25 \mu \mathrm{l}$ of genistein or daidzein (4x target concentrations) were added to achieve a final concentration equal to one-half of EC50 for each isoflavone. The final range of methotrexate concentrations were $0,1,2,5,10$, 20 and $100 \mu \mathrm{M}$. The cells were incubated for 72 hours and subjected to MTT assay as describe above. Combination test involved 3-independent experiments with 6 microwells per each treatment concentration $(n=18)$.

\subsection{Data and Statistical Analysis}

Experimentally values for cell viability were fitted by non-linear regression (NLR) to the Logistics function shown below, where PRED is the predicted response, $\mathrm{C}=$ minimum response, and $M=$ maximum response. $E$ is $50 \%$ effect dose or drug-dose, which produces a $50 \%$ response (E50), and B is the steepness of the curve [13].

$$
\text { PRED }=\mathrm{C}+\left((\mathrm{M}-\mathrm{C}) /\left(1+\mathrm{EXP}\left(\mathrm{B}^{*} \operatorname{Ln}(\mathrm{D} / \mathrm{E})\right)\right)\right)
$$

NLR was implemented using SPSS software (IBM SPSS v21.). Estimates for EC50 were subjected to isobologram analysis. Doseresponse data were also analyzed median effect model. The fraction of affected cells ( $\mathrm{Fa}$ ) and unaffected cells $(\mathrm{Fu})$ are calculated for different doses of drug ( $\mathrm{Fa}=100-\%$ viable cells $/ 100$ and $\mathrm{Fu}=1-\mathrm{Fa})$. A plot of $\log (\mathrm{Fa} / \mathrm{Fu})$ versus drug concentration was fitted to a straight-line graph $(\mathrm{Y}=\mathrm{mx}+\mathrm{c})$ to determine the median effect dose $(\mathrm{Dm})$ and slope $(\mathrm{m})$ using CompuSyn ${ }^{\mathrm{TM}}$ software [12]. Values for the combination Index (Cl) were calculated either manually or via CompuSyn ${ }^{\mathrm{TM}}$. To determine $\mathrm{Cl}$ manually, we used the relations below, where $d_{50} \mathrm{MTX}$ and $d_{50}$ Gen are the $50 \%$ effect dose from combination studies, and $\mathrm{EC} \mathrm{O}_{1}$ and $\mathrm{EC} \mathrm{O}_{2}$ are values for each agent alone.

$$
C I=\frac{d_{50} M T X}{E C 501}+\frac{d_{50} G e n}{E C 502}
$$

The size of $\mathrm{Cl}$ is indication whether combination therapies produce synergism $(\mathrm{Cl}<1.0)$, antagonism $(\mathrm{Cl}>1.0)$ or additive behavior $(\mathrm{Cl}=1.0)[13]$.

\section{RESULTS}

\subsection{Dose-response Parameters}

Table 1 and Fig. 1 show dose-effect parameters for MDA-MB-231 cells treated with methotrexate, genistein or daidzein determined using a logistic function to fit experimental data. There was a good fit for NLR predictions with observed points $(\mathrm{R} 2=0.98-0.99)$. Table 2 shows dose-effect parameters arising from CompuSyn ${ }^{\mathrm{TM}}$ analysis of the same data. The median dose (Dm) corresponds to the $50 \%$ effect dose (EC50) and slope $(\mathrm{m})$ is a measures of the steepness of the plot of $\log (\mathrm{Fa} / \mathrm{Fu})$ versus drug concentration.
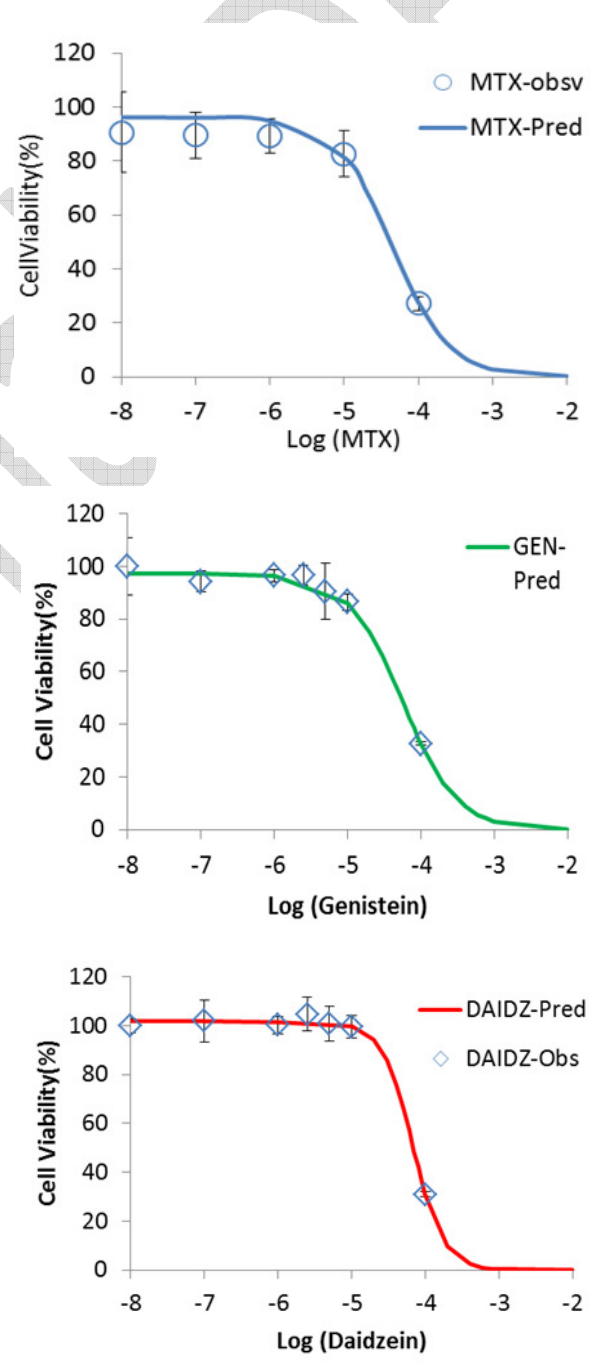

Fig. 1. Dose response curve for MDA-MB-231 breast cancer cells treated with methotrexate, genistein or daidzein as single treatments

Continuous lines shows response predicted by NLR. Experimental points are shown as means $\pm S D(n=12)$ from two independent experiments 
Table 1. Dose-response parameters for MDA-MB-231 breast cancer cells treated using methotrexate and isoflavones determined by non-linear regression analysis (SPSS)

\begin{tabular}{llll}
\hline Agent/ NLR parameter & $\mathrm{EC50}(\mathrm{E}) \boldsymbol{\mu M}$ & Slope (B) & Max (M) \\
\hline Methotrexate & $44.7 \pm 6.4$ & $1.14 \pm 0.29$ & $96.2 \pm 3.3$ \\
Genistein & $55.8 \pm 3.9$ & $1.17 \pm 0.11$ & $97.4 \pm 1.7$ \\
Daidzein & $67.4 \pm 12.2$ & $2.1 \pm 2.20$ & $102.0 \pm 1.0$ \\
Methotrexate $(+30 \mu \mathrm{M}$ Genistein) & $57.6+2.0$ & $0.62 \pm 0.04$ & $99.0 \pm 0.54$ \\
Methotrexate $(+30 \mu \mathrm{M}$ Daidzein) & $29.7 \pm 2.4$ & $0.40 \pm 0.02$ & $111 \pm 2.0$ \\
\hline
\end{tabular}

Data shows mean $\pm S E M$ as determined by NLR with bootstrap; Parameters are EC50 (E), response slope $(B)$ and maximum cell viability (Max). The lower-limit for cell viability (C) was constrained as zero during NLR

Table 2. Dose-response parameters for MDA-MB-231 breast cancer cell treated with methotrexate, genistein or daidzein as determined by CompuSyn *

\begin{tabular}{llll}
\hline Agent/parameter & $\operatorname{Dm}(\mu \mathrm{M})$ & Slope $(\mathbf{m})$ & $\mathbf{r}$ \\
\hline Methotrexate & $42.1 \pm 5.0$ & $0.46 \pm 0.08$ & $0.916 \pm 0.005$ \\
Genistein & $50.4 \pm 2.6$ & $0.88 \pm 0.31$ & $0.996 \pm 0.064$ \\
Daidzein & $64.1 \pm 1.5$ & $1.90 \pm 0.18$ & $0.911 \pm 0.005$ \\
\hline${ }^{*}$ Mean $\pm S D$, from two independent experiments with 6 replicates per drug dose, $n=12$. & Dm = median dose $(\mu M)$, \\
& $m=$ response slope, $r=$ regression coefficient
\end{tabular}

Results for NLR analysis of treatments combining methotrexate and genistein or daidzein are shown in Fig. 2. Isobologram analysis predicted EC50 values for methotrexate of $20-22 \mu \mathrm{M}$ in the presence $30 \mu \mathrm{M}$ daidzein $(\sim 1 / 2$ EC50 dose). The actual EC50 values observed by for methotrexate combinations with genistein or daidzein are shown Table 1.
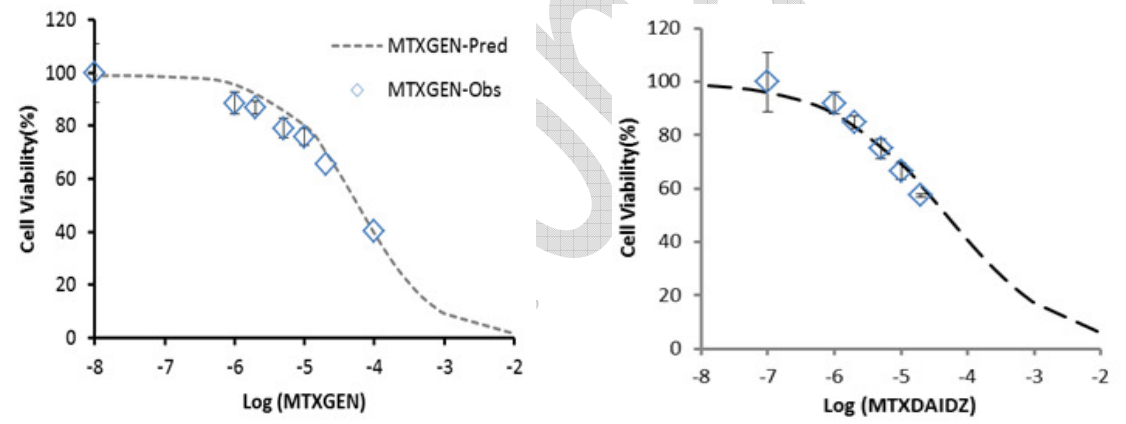

Fig. 2. Combination treatment of MDA-MB-231 breast cancer cells using methotrexate and isoflavones

Notes (left panel) methotrexate plus genistein (MTXGEN), (Right-panel) methotrexate plus daidzein (MTXDAIDZ)
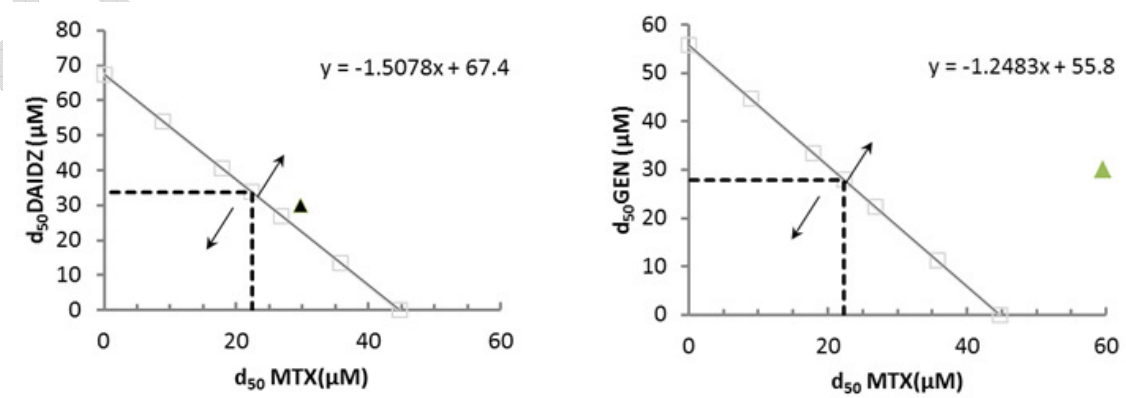

Fig. 3. Isobologram for methotrexate combination with daidzein or genistein

The iso-effective doses predicted to produce $50 \%$ effect when daidzein (DAIDZ) or genistein (GEN) is added with methotrexate (MTX) in a variety of doses; $(\bullet)=$ observed EC50 for combination studies. Dotted = predicted in this study for additive (no interaction) response between two agents 
The combination index $(\mathrm{Cl})$ value using data from Table 1 was $\mathrm{Cl}=1.9$ for methotrexate-genistein and $\mathrm{Cl}=1.1$ for methotrexate-daidzein combination at the concentrations corresponding to $50 \%$ effect. The values for $\mathrm{Cl}$ were predicted to increase from 1.1 to 5.0 (Fig. 4) with decreasing methotrexate: isoflavone ratio (Fig. 4).

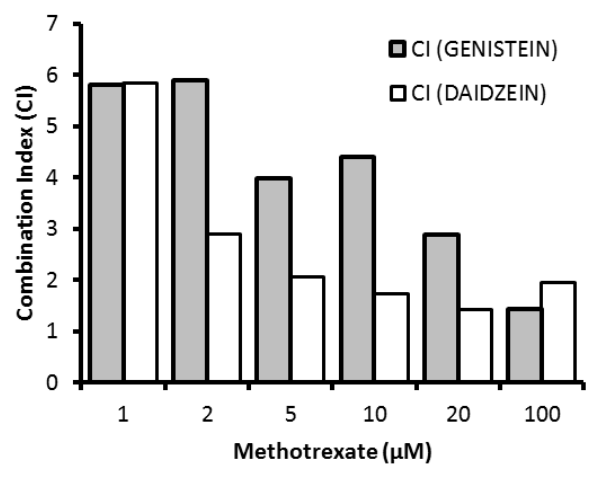

Fig. 4. A plot of combination index (Cl) values for treatment of MDA-MB-231 breast cancer cells with methotrexate (1-100 $\mu \mathrm{M})$ and $30-\mu \mathrm{M}$ daidzein or genistein

Data generated using CompuSyn analysis

\section{DISCUSSION}

Methotrexate is an anticancer agent [1-3,14]. Consumption of soy isoflavones is thought to reduce the risk of breast cancer $[8,9,10]$. Methotrexate inhibits cell proliferation by blocking the enzyme dihydrofolate reductase (DHFR), depleting the intracellular pool of folate, and by restriction of methyl-group availability for DNA synthesis [1]. In addition, exposure to methotrexate increases intracellular oxidative stress due to the inhibition of $\mathrm{NAD}(\mathrm{P}) \mathrm{H}$-liked reductases $[14,15]$. Soy isoflavones show estrogen receptor activation, tyrosine kinase inhibition, induction of cell-cycle arrest, antiinflammatory action, and general antioxidant activity $[10,16,17]$. For the preceding reasons, we tested the hypothesis that combination of methotrexate with isoflavones would produce enhanced anti-cancer activity compared with each agent alone.

EC50 values from this study (Table 1) are in broad agreement with previous reports, taking account of differences in assay conditions, e.g. different culture medium, and drug exposure times. The EC50 was $80 \mu \mathrm{M}$ for methotrexate treatment of MDA-MB-231 cultured with MEM media and a drug exposure time of $24 \mathrm{hrs}$ [18]. By comparison, EC50 was $18.5 \mu \mathrm{M}$ methotrexate with low protein (5\% FBS) medium [19]. Tests using genistein and MDA-MB-231 cells showed that EC50 ranges from $46.8 \mu \mathrm{M}$ [20] to $50-90 \mu \mathrm{M}$ $[21,22]$ depending on the exposure time and other assay conditions.

There was antagonism between methotrexate and soy isoflavones in this study. The EC50 for methotrexate increased from $44.7 \mu \mathrm{M}$ to $57.6 \mu \mathrm{M}$ in the presence of genistein with $\mathrm{Cl}>1.0$ indicating antagonism. The EC50 value for methotrexate with daidzein present $(29.7 \mu \mathrm{M})$ was closer to values $(20-22 \mu \mathrm{M})$ predicted by isobologram analysis (Fig. 3) for additive response meaning neither positive nor negative interaction (Table 1 and Fig. 3.) but here also $\mathrm{Cl}$ $>1.0$. For both isoflavones $\mathrm{Cl}>1.0$ indicating antagonism. The degree antagonism between methotrexate and genistein seem to be greater than those with daidzein. CompuSyn ${ }^{T m}$ predictions showed decreasing antagonism (Fig. 4) with increasing methotrexate: isoflavones ratio.

Relating in-vitro data to human exposure conditions requires that EC50s are subjected to in-vitro, in vivo extrapolation (IVIVE) by stepwise correction for the effects of absorption, serum protein binding, liver metabolism and renal clearance $[23,24]$. Past literature, data may be useful also for addressing IVIVE issues. Briefly, it is known that methotrexate is bioavailable and oral doses of $<20 \mathrm{mg} / \mathrm{m}^{2} \quad(<0.54 \mathrm{mg} / \mathrm{Kg})$ methotrexate are $50-95 \%$ absorbed leading to peak plasma concentrations of $300-2000 \mu \mathrm{M}$ within 1.5-3 hours and a half-life of elimination of 4-6h [3]. Most of the circulating methotrexate is excreted via the kidneys in an intact form with $<10 \%$ metabolism in the liver to form $7-\mathrm{OH}$ methotrexate [3]. On the other hand, the plasmaconcentration profile for soy isoflavones is influenced by a host of factors, e.g. relative proportion of aglycone and glycosylated forms, type of food matrix used for administration, and forms of processing [25]. Using the dose for genistein or daidzein frequently used in human trials $(45-56 \mathrm{mg} / \mathrm{day})$, the fractional excretion rate (apparent bioavailability) was $20-50 \%$ with a peak plasma concentration of 2-5 $\mu \mathrm{M}$ some 48hrs after intake [26]; reviewed by [27]. On the basis of such data $[3,26,27]$, a typical exposure to $20 \mathrm{mg}$ methotrexate $+56 \mathrm{mg}$ genistein would produce plasma concentrations for methotrexate that are 60-400 times higher compared to the peak plasma concentration for isoflavone. Moreover, the peak concentrations for isoflavone would occur after the peak for methotrexate $[3,26,27]$. According to the present paper high 
methotrexate: isoflavone ratios are not conducive for antagonism.

Evidence is emerging that antioxidant phytochemicals can reduce toxicity to healthy cells, whilst not affecting efficacy [4-7] depending on changes to absorption, metabolism, distribution and excretion (ADME) characteristics $[15,28,29,30]$. Research using leukemic cells showed that genistein inhibits methotrexate uptake by the reduced folate transporter owing to its role as tyrosine kinase inhibitor [31,32,33]. Genistein was found to promote the transcription of efflux transporter (ABCC1/MRP1) protein for MDA-MB-231 cells with no net effect onmitoxantrone toxicity owing to the simultaneous inhibition of the same transporter [34]. Many polyphenols from beverages were also reported to inhibit methotrexate and folate uptake at low $\mathrm{pH}$ involving the proton coupled folate transporter [35-39]; genistein had no effect on the low-pH uptake of methotrexate and folate by $\mathrm{CaCo} 2$ cells [35]. Interestingly, genistein was reported to moderate genes from MDA-MB-231 cells suppressed by epigenetic mechanism [21] thereby increasing the cell sensitivity to therapeutic drugs. In general, methotrexate toxicity would be enhanced by phytochemicals that increase uptake, promote methotrexate modification to polyglutamated forms, and / or decrease methotrexate efflux [15]. For example, genistein (and its metabolites) were found to be inhibitors for breast cancer resistant protein (ABCG2/BCRP) efflux transporter [40,41]. Methotrexate and 7-OH methotrexate were also identified as substrates for ABCC2 (MRP2), ABCC3 (MRP3), and ABCG2/BCRP) and found to have an enormous impact on drug concentration profile [29].

\section{CONCLUSION}

In conclusion, a diverse range of potential interactions may occur between genistein and methotrexate that go to produce antagonism with regard to cytoxicity for MDA-MB-231 cells. The results from this study show a rising tolerance of breast cancer cells towards methotrexate in the presence of genistein. However, we speculate that antagonism is unlikely where concentrations for methotrexate are much higher than genistein. More research is needed also to consider methotrexate interactions with isoflavones in terms of changes to ADME and the consequences for other health outcomes. The different levels of antagonism observed for methotrexate and genistein or daidzein is interesting and worthy of further study. There is scope also to consider the possible role of soy isoflavone/ MTX therapy on immune responses or rheumatoid arthritis $[1,3,8,14,35,36]$.

\section{COMPETING INTERESTS}

Authors have declared that no competing interests exist.

\section{REFERENCES}

1. Gonen N, Assaraf YG. Antifolates in cancer therapy: Structure, activity and mechanisms of drug resistance. Drug Resist Updat. 2012;15(4):183-210.

PMID: 22921318

DOI: 10.1016/j.drup.2012.07.002

2. Fotoohi AK, Albertioni F. Mechanisms of antifolate resistance and methotrexate efficacy in leukemia cells. Leuk Lymphoma. 2008;49(3):410-26.

PMID: 18297517 DOI: $10.1080 / 10428190701824569$

3. Schmiegelow K. Advances in individual prediction of methotrexate toxicity: A review. Br J Haematol. 2009;146(5):489503.

PMID: 19538530

DOI: 10.1111/j.1365-2141.2009.07765.x

4. Nakayama A, Alladin KP, Igbokwe O, White JD. Systematic review: Generating evidence-based guidelines on the concurrent use of dietary antioxidants and chemotherapy or radiotherapy. Cancer Invest. 2011;29(10):655-67.

PMCID: PMC3666569

DOI: $10.3109 / 07357907.2011 .626479$

5. Lawenda BD, Kelly KM, Ladas EJ, Sagar SM, Vickers A, Blumberg JB. Should supplemental antioxidant administration be avoided during chemotherapy and radiation therapy?. J Natl Cancer Inst. 2008;00(11):773-83.

PMID: 18505970

DOI: $10.1093 /$ jnci/djn148

6. Block KI, Koch AC, Mead MN, Tothy PK, Newman RA, Gyllenhaal C. Impact of antioxidant supplementation on chemotherapeutic toxicity: A systematic review of the evidence from randomized controlled trials. Int J Cancer. 2008; 123(6):1227-39.

PMID: 18623084

DOI: $10.1002 / \mathrm{ijc} .23754$

7. He FJ, Chen JQ. Consumption of soybean, soy foods, soy isoflavones and breast 
cancer incidence: Differences between Chinese women and women in Western countries and possible mechanisms. Food Science and Human Wellness. 2013;2(3): 146-61.

Available:https://doi.org/10.1016/j.fshw.201 3.08.002

8. Funk-Archuleta MA, Foehr MW, Tomei LD, Hennebold KL, Bathurst IC. A soyderived antiapoptotic fraction decreases methotrexate toxicity in the gastrointestinal tract of the rat. Nutr Cancer. 1997;29(3): 217-21.

Available:http://dx.doi.org/10.1080/016355 89709514627

9. Kwon Y. Effect of soy isoflavones on the growth of human breast tumors: Findings from preclinical studies. Food Sci Nutr. 2014;2(6):613-22.

PMC4256563

DOI: $10.1002 / \mathrm{fsn} 3$

10. Banerjee S, Li Y, Wang Z, Sarkar FH. Multi-targeted therapy of cancer by genistein. Cancer Lett, 2008;269(2):22642.

PMC2575691

DOI: 10.1016/j.canlet.2008.03.052

11. Zhou JR. Soy-food and soy-drug interactions in prevention and treatment of cancer. In Thompson LU, Ward WE, editors. Food-drug synergy and safety,Taylor Francis: Boca Raton;2006 Available:https://doi.org/10.1201/97814200 38255.sec3

12. Chou, T-C, Martin N. CompuSyn for drug combinations and for general dose-effect analysis; 2015.

Available:http://www.combosyn.com/featur e.html

(Accessed $17^{\text {th }}$ Oct 2016)

13. Breitinger HG. Drug synergy-mechanisms and methods of analysis. In William A, editor. Toxicity and drug Testing. INTECH; 2012.

DOI: $10.5772 / 30922$

14. Van Outryve S, Schrijvers D, Van Den Brande J, Wilmes P, Bogers J, Van Marck E, Vermorken JB. Methotrexate-associated liver toxicity in a patient with breast cancer: Case report and literature review. Neth $\mathrm{J}$ Med. 2002;60(5):216-22.

PMID: 12365478

15. Hess JA, Khasawneh MK. Cancer metabolism and oxidative stress: Insights into carcinogenesis and chemotherapy via the non-dihydrofolate reductase effects of methotrexate. BBA Clin. 2015;3:152-61. PMCID: PMC4661551

DOI: 10.1016/j.bbacli.2015.01.006
16. Levitt ML, Koty PP. Tyrosine kinase inhibitors in preclinical development. Invest New Drugs. 1999;17(3):213-26.

PMID: 10665475

17. Sarkar FH, Li Y. Using chemopreventive agents to enhance the efficacy of cancer therapy. Cancer Res. 2006;66(7):3347-50. PMID: 16585150

DOI: 10.1158/0008-5472.CAN-05-4526

18. Wu Z, Shah A, Patel N, Yuan X. Development of methotrexate proline prodrug to overcome resistance by MDAMB-231 cells. Bioorg Med Chem Lett. 2010;20(17):5108-12.

PMID: 20674353

DOI: 10.1016/j.bmcl.2010.07.024

19. Lindgren M, Rosenthal-Aizman K, Saar K, Eiríksdóttir $E$, Jiang $Y$, Sassian $M$, et al. Overcoming methotrexate resistance in breast cancer tumor cells by the use of a new cell-penetrating peptide. Biochem Pharmacol. 2006;71(4):416-25.

PMID: 16376307

DOI: 10.1016/j.bcp.2005.10.048

20. He FJ, Wang J, Niu JZ, Wang JF. The inhibiting effect of genistein on the growth of human breast cancer cells in vitro. Zhongguo Zhong yao za zhi= Zhongguo zhongyao zazhi= China journal of Chinese Materia Medica. 2002 Dec;27(12):936-9.

9 [In Chinese]

PMID: 12776537

21. Li Y, Chen H, Hardy TM, Tollefsbol TO. Epigenetic regulation of multiple tumorrelated genes leads to suppression of breast tumorigenesis by dietary genistein. PLoS One. 2013;8(1):e54369.

PMCID: PMC3544723

DOI: 10.1371/journal.pone.0054369

22. Uifălean $A$, Schneider $S$, Gierok $P$, lonescu $\mathrm{C}$, luga $\mathrm{CA}$, Lalk $\mathrm{M}$. The impact of soy isoflavones on MCF-7 and MDA-MB231 breast cancer cells using a global metabolomic approach Int J Mol Sci. 2016; 17(9):1443.

PMC: 5037722

DOI: 10.3390/ijms17091443

23. Yoon M, Campbell JL, Andersen ME, Clewell HJ. Quantitative in vitro to in vivo extrapolation of cell-based toxicity assay results. Crit Rev Toxicol. 2012;42(8):63352.

PMID: 22667820, DOI: 10.3109/10408444.2012.692115

24. Wetmore BA, Wambaugh JF, Allen B, Ferguson SS, Sochaski MA, Setzer RW, 
et al. Incorporating high-throughput exposure predictions with dosimetryadjusted in vitro bioactivity to inform chemical toxicity testing. Toxicol Sci. 2015; 148(1):121-36.

PMCID: PMC4620046

DOI: $10.1093 /$ toxsci/kfv171

25. Williamson G, Manach C. Bioavailability and bioefficacy of polyphenols in humans. II. Review of 93 intervention studies. Am J Clin Nutr. 2005;81(1):243S-55S.

PMID: 15640487

26. Setchell KD, Brown NM, Desai P, ZimmerNechemias L, Wolfe BE, Brashear WT, et al. Bioavailability of pure isoflavones in healthy humans and analysis of commercial soy isoflavone supplements. J Nutri. 2001;131(4 Suppl):1362S-75S.

PMID: 11285356;

27. Manach C, Williamson G, Morand C, Scalbert A, Rémésy $C$. Bioavailability and bioefficacy of polyphenols in humans. I. Review of 97 bioavailability studies. Am J Clin Nutr. 2005;81(1):230S-42S.

PMID: 15640486

28. Köhle $\mathrm{C}$, Bock KW. Coordinate regulation of Phase I and II xenobiotic metabolisms by the Ah receptor and Nrf2. Biochem Pharmacol. 2007;73(12):1853-62.

PMID: 17266942

DOI: 10.1016/j.bcp.2007.01.009

29. Moon YJ, Wang X, Morris ME. Dietary flavonoids: effects on xenobiotic and carcinogen metabolism. Toxicol In vitro. 2006;20(2):187-210.

PMID: 16289744.

DOI: 10.1016/j.tiv.2005.06.048

30. Vlaming $M L$, van Esch $A$, van de Steeg $E$, Pala Z, Wagenaar $E$, van Tellingen $O$, et al.. Impact of abcc2 [multidrug resistanceassociated protein (MRP) 2], abcc3 (MRP3), and abcg2 (breast cancer resistance protein) on the oral pharmacokinetics of methotrexate and its main metabolite 7-hydroxymethotrexate. Drug Metab Dispos. 2011;39(8):1338-44. PMID: 21566011

DOI: $10.1124 /$ dmd.111.038794

31. Xuan YO, Hacker MP, Tritton TR, Bhushan $\mathrm{AL}$. Modulation of methotrexate resistance by genistein in murine leukemia L1210 cells. Oncology Rep. 1998;5(2):419-40. PMID: 9468571

32. Bhushan A, Hacker MP, Tritton TR. Collateral methotrexate resistance in cisplatin-selected murine leukemia cells. Braz J Med Biol Res. 1999;32(7):827-33. PMID: 10454740
33. Liu T, Singh R, Rios Z, Bhushan A, Li $M$, Sheridan PP, et al. Tyrosine phosphorylation of HSC70 and its interaction with RFC mediates methotrexate resistance in murine $\mathrm{L} 1210$ leukemia cells. Cancer Lett. 2015;357(1): 231-41.

PMCID: PMC4785865

DOI: 10.1016/j.canlet.2014.11.036

34. Rigalli JP, Tocchetti GN, Arana MR, Villanueva SS, Catania VA, Theile D, et al. The phytoestrogen genistein enhances multidrug resistance in breast cancer cell lines by translational regulation of $A B C$ transporters. Cancer Lett. 2016;376(1): 165-72.

PMID: 27033456

DOI: 10.1016/j.canlet.2016.03.040

35. Lemos C, Peters GJ, Jansen G, Martel F, Calhau C. Modulation of folate uptake in cultured human colon adenocarcinoma Caco-2 cells by dietary compounds. Eur $\mathrm{J}$ Nutr. 2007;46(6):329-36.

PMID: 17712586

DOI: 10.1007/s00394-007-0670-y

36. Martel F, Monteiro R, Calhau C. Effect of polyphenols on the intestinal and placental transport of some bioactive compounds. Nutrition Res Rev. 2010;23(1):47-64.

PMID: 20392307

DOI: $10.1017 /$ S0954422410000053

37. Furumiya M, Inoue K, Nishijima C, Yamashiro T, Inaoka E, Ohta K, et al. Noncompetitive inhibition of protoncoupled folate transporter by myricetin. Drug Metab Pharmacokinet. 2014;29(4): 312-6.

PMID: 24492671

38. Kissei M, Itoh $T$, Narawa $T$. Effect of epigallocatechin gallate on drug transport mediated by the proton-coupled folate transporter. Drug Metab Pharmacokinet. 2014;29(5):367-72.

PMID: 24695276

39. Furumiya $\mathrm{M}$, Yamashiro $\mathrm{T}$, Inoue $\mathrm{K}$, Nishijima C, Ohta K, Hayashi Y, et al. Sustained inhibition of proton-coupled folate transporter by myricetin. Drug Metab Pharmacokinet. 2015;30(2):154-9.

PMID: 25801697

DOI: 10.1016/j.dmpk.2014.11.001

40. Álvarez Al, Vallejo F, Barrera B, Merino G, Prieto JG, Tomás-Barberán $F$, et al. Bioavailability of the glucuronide and sulfate conjugates of genistein and daidzein in breast cancer resistance 
protein 1 knockout mice. Drug Metab Dispos. 2011;39(11):2008-12.

PMID: 21828252

DOI: $10.1124 / \mathrm{dmd} .111 .040881$

41. Perez M, Otero JA, Barrera B, Prieto JG, Merino G, Alvarez Al. Inhibition of
ABCG2/BCRP transporter by soy isoflavones genistein and daidzein: Effect on plasma and milk levels of danofloxacin in sheep. Vet J. 2013;196(2):203-8.

PMID: 23083838

DOI: $10.1016 /$ j.tvjl.2012.09.012

(0) 2017 Maginnes and Owusu-Apenten; This is an Open Access article distributed under the terms of the Creative Commons Attribution License (http://creativecommons.org/licenses/by/4.0), which permits unrestricted use, distribution, and reproduction in any medium, provided the original work is properly cited.

Peer-review history:

The peer review history for this paper can be accessed here: http://sciencedomain.org/review-history/20202 